Pak. J. Agri. Sci., Vol. 53(1), 17-25; 2016

ISSN (Print) 0552-9034, ISSN (Online) 2076-0906

DOI: $10.21162 / P A K J A S / 16.4766$

http://www.pakjas.com.pk

\title{
SALINITY IMPAIRS IONIC, PHYSIOLOGICAL AND BIOCHEMICAL ATTRIBUTES IN POTATO
}

\author{
Hafiz Nazar Faried ${ }^{1, *}$, C.M. Ayyub ${ }^{1}$, Muhammad Amjad ${ }^{1}$ and Rashid Ahmed ${ }^{2}$ \\ ${ }^{1}$ Institute of Horticultural Sciences, University of Agriculture, Faisalabad, Pakistan; \\ ${ }^{2}$ Department of Agronomy, University of Agriculture, Faisalabad, Pakistan. \\ "Corresponding author's e-mail: hnfw1118@gmail.com
}

\begin{abstract}
Salt stress is hampering plant growth and development especially in arid and semiarid regions due to enhanced evapotranspiration and underground brackish irrigation water. A pot experiment was therefore conducted to assess the malicious effects of salinity on two potato (Solanum tuberosum L.) cultivars namely N-Y LARA and 720-110 NARC. Various salinity levels (control, 2.5, 5.0, 7.5, 10.0 and $12.5 \mathrm{dS} \mathrm{m}^{-1}$, developed with $\mathrm{NaCl}$ ) were induced after 30 days of tuber emergence. Both the cultivars proved to be significantly $(\mathrm{p} \leq 0.05)$ affected by salt stress. However, N-Y LARA was less affected than 720-110 NARC. Salinity stress drastically reduced potassium $\left(\mathrm{K}^{+}\right)$contents, protein contents, water relations and gas exchange attributes. However, sodium $\left(\mathrm{Na}^{+}\right)$contents, $\mathrm{Na}^{+}: \mathrm{K}^{+}$ratio, leaf electrolyte leakage, proline contents, melondialdehyde (MDA) contents and antioxidant enzymes activities like superoxide dismutase (SOD), catalase (CAT) and peroxidase (POD) were increased with increasing salinity stress. Conclusively, salt tolerance potential is cultivar dependent as both cultivars exhibited diverse performance vis-à-vis various studied attributes against different $\mathrm{NaCl}$ levels.
\end{abstract}

Keywords: Potato, salinity, $\mathrm{Na}^{+}: \mathrm{K}^{+}$ratio, water relations, gas exchange, antioxidants.

\section{INTRODUCTION}

Agriculture is one of the most exposed sectors to vagaries of climate change (Malik, 2012). Around 20-25\% of the world (Munns and Tester, 2008) and 26\% of Pakistan's agricultural (Anonymous, 2010) irrigated lands are affected by salinity. Saline area is increasing day by day due to higher evapotranspiration that demand more irrigation and consequently, more salt accumulation in the root zone especially in arid and semiarid regions of the world (Iqbal et al., 2009; Mou, 2011). Predominately, salinization (50-80\%) is caused by $\mathrm{NaCl}$ salt (Kaouther, 2012). Primary toxic ion is $\mathrm{Na}^{+}$as it not only impairs $\mathrm{K}^{+}$uptake but also interrupts regulation of stomata which eventually causes water loss. $\mathrm{Na}^{+}$enters in leaf apoplast through xylem stream and left behind as water evaporates. $\mathrm{Na}^{+}$mainly compete and occupies cations binding sites by reducing uptake and transport of $\mathrm{Ca}^{+2}$ and $\mathrm{K}^{+}$(Munns and Tester, 2008; Horie et al., 2012; Hasanuzzaman et al., 2013). Hyperosmotic accompanied with hyper ionic conditions enhance generation of reactive oxygen species (ROS) damaging the proteins, lipids, DNA and carbohydrates molecules, which weakens the plant defense mechanism and modifies membrane structures and its composition (Tuteja, 2007; Ismail, 2014; Jbir-Koubaa, 2014; Gao et al., 2015). Moreover, ROS intensifies MDA contents, deactivates enzymes, disrupts ions of normal cellular metabolism and enhances electrolyte leakage that causes programmed cell death (necroptosis) and reduced photosynthetic activity (Gao et al., 2015). Therefore, plants manifest various scavenging machineries like enzymatic antioxidant system (SOD, CAT, POD), the level of which is elevated during abiotic stresses (Gill and Tuteja, 2010; Choudhury, 2013; Ismail, 2014). It also affects plant water relations and gas exchange attributes together with metabolic toxicity, reduction in green pigments and thereby intervening photosynthetic activity (Ashraf and Harris, 2013; Gupta and Huang, 2014; Li et al., 2014). Potato (Solanum tuberosum L.) is a staple food for about 50\% world's population and third largest crop in human consumption. It is fourth major crop with respect to area and production in the world. It provides high energy per unit land, water and time along-with valuable source of vitamins and minerals (Abhayapala et al., 2014; Gao et al., 2015). It is moderately salt-sensitive (Mitsuya et al., 2000) with $50 \%$ growth and yield reduction at $5 \mathrm{dSm}^{-1}$ salt stress (Hmida-Sayari et al., 2005). However, tolerance level varies from cultivar to cultivar (Bruns and HechtBuchholz, 1990). Increasing saline area demands salt tolerant cultivars for sustainable potato production (Mou, 2011). Hence, it is necessary to understand salinity tolerance mechanism in potato, helpful in developing stress tolerant potato cultivars by using various modern techniques (Gururani et al., 2013). Considering this scenario, present experiment was conducted to assess adverse effects of salinity stress on ionic 
imbalance, water relations, gas exchange, antioxidant enzymes and biochemical attributes of two potato cultivars.

\section{MATERIALS AND METHODS}

Plant materials and experiment details: The study was carried out in the lath house at Institute of Horticultural Sciences, University of Agriculture, Faisalabad, Pakistan during autumn season, 2012-13. It was a pot (9 L, imperforated) experiment containing sand as growing medium. Two potato cultivars namely NY-LARA and 720110 NARC were used in this study. Moreover, there were four replications and each treatment in every replication was comprised of three pots. Five tubers were planted in each pot. After the emergence of tubers, three plants in each pot were maintained for data collection. Half strength Hoagland solution was used as nutrient medium. Pots were irrigated according to need of plants by visual observing moisture status of sand. After 30 days of tuber's emergence, plants were subjected to six different $\mathrm{NaCl}$ concentrations i.e. 0.0, 2.5, 5.0, 7.5, 10.0 and $12.5 \mathrm{dS} \mathrm{m}^{-1}$. To avoid osmotic shock to growing potato plants, salt concentrations were applied gradually in several steps ( $2.5 \mathrm{dS} \mathrm{m}^{-1}$ every two days). After 10 days of treatment application, fully expanded fourth leaf from the apex was used to measure data regarding various ionic, water relation, gas exchange, antioxidant enzymes and biochemical parameters.

Ionic attributes: Leaf $\mathrm{Na}^{+}$and $\mathrm{K}^{+}$were determined by a method described by Yoshida et al. (1971) through flame photometer.

Water relation attributes: Pre-dawn leaf water potential $\left(\Psi_{\mathrm{w}}\right)$ (-MPa) was determined with pressure chamber (manually tightened seal type, model 1000, PMS Instrument Company, Albany, USA) for which leaf was placed in gasket of pressure chamber (Model, 615, USA) to determine $\Psi \mathrm{w}$. The leaves used for $\Psi_{\mathrm{w}}$ were stored at $-20^{\circ} \mathrm{C}$ to determine osmotic potential $(\Psi \pi)$ (-MPa) by osmometer (Vapro-5520, Wescor Inc. U.S.A). Turgor potential ( $\Psi p$ ) (MPa), the difference between $\Psi_{\mathrm{w}}$ and $\Psi \pi$ potential, was measured by using the equation: $\Psi p=\Psi_{\mathrm{w}}-\Psi \pi$. Water use efficiency (WUE), a ratio between photosynthetic rate $(P n)$ and transpiration rate $(E)$, was measured by equation: Leaf relative water contents (LRWC) were calculated based on the method of Yamasaki and Dillenburg (1999) by following formula:

$$
L R W C=\frac{F M-D M}{T M-D M} \times 100
$$

Gas exchange attributes: Gas exchange attributes (photosynthesis rate $(P n)$, stomatal conductance $(g s)$ and transpiration rate $(E)$ were assessed from intact leaves with an open LCi Portable Photosynthesis System (infrared gas analyzer) (ADC Bio-Scientific Ltd. Hoddesdon, Herts,
EN11, England) from 10:30 am to $12: 30 \mathrm{pm}$, operated at light intensity range of $674-943 \mu \mathrm{mol} \mathrm{m} \mathrm{m}^{-2} \mathrm{~s}^{-1}$, leaf surface area of $6.25 \mathrm{~cm}^{2}$, ambient $\mathrm{CO}_{2}$ concentration (Cref) range of 395-440 $\mathrm{mmol}^{-1}$, temperatures range of leaf chamber (27.4$\left.34.9^{\circ} \mathrm{C}\right)$ and surface $\left(28.2-35.7^{\circ} \mathrm{C}\right)$, flow rate of air per unit leaf area (U) $200.78 \mu \mathrm{mol} \mathrm{s}{ }^{-1}$, ambient atmospheric pressure (P) of $995 \mathrm{mBar}, \mathrm{H}_{2} \mathrm{O}$ partial pressure of $14.6 \mathrm{mBar}$ and boundary resistance to $\mathrm{H}_{2} \mathrm{O}$ at full flow $(\mathrm{rb})$ was $0.17 \mathrm{~m}^{2} \mathrm{~s}$ $\mathrm{mol}^{-1}$.

Membrane stability index: Membrane stability index (an indication of salt stress tolerance) was determined by measuring leaf electrolyte leakage (LEL) according to a method described by Farkhondeh et al. (2012) by using an equation:

Antioxidant activities: For the estimation of antioxidant activities, fresh leaves $(0.5 \mathrm{~g})$ were grounded in an icecooled tissue grinder in $05 \mathrm{ml}$ of $50 \mathrm{mM}$ cooled phosphate buffer ( $\mathrm{pH}$ 7.8). The homogeneous mixture was centrifuged at $15000 \mathrm{~g}$ for $20 \mathrm{~min}$ at $4^{\circ} \mathrm{C}$. The supernatant was used for determining activities of the following enzymes. Superoxide dismutase (SOD) activity was analyzed according to the protocol of Giannopolitis and Ries (1977). Catalase (CAT) and peroxidase (POD) activities were estimated by the method of Chance and Maehly (1955).

Biochemical attributes: Protocol of Lowry et al. (1951) was followed to measure total soluble protein contents in leaves. The proline contents (first biochemical marker under abiotic stresses) were calculated according to the method of Bates $e t$ al. (1973). The total phenolic and MDA contents were estimated by using the protocol of Julkunen-Titto (1985) and Heath and Packer (1968), respectively.

Correlation matrix: Pearson Correlation Matrix of $\mathrm{Na}^{+}$with $\mathrm{K}^{+}, P n$, WUE, LEL, SOD, CAT, Proline and MDA was estimated by employing Statistix 8.1 software to evaluate the interdependence between the attributes.

Statistical analysis: Research was executed in completely randomized design with four replications. Analysis of variance of all studied parameters was computed by using Statistix 8.1 software and comparison of means was done using Tukey HSD test.

\section{RESULTS}

Application of various $\mathrm{NaCl}$ levels (control (non-saline), 2.5, 5.0, 7.5, 10.0 and $12.5 \mathrm{dS} \mathrm{m}^{-1}$ ) affected both the tested potato cultivars significantly $(\mathrm{p} \leq 0.05)$ which confirmed by using ANOVA and comparison of means through Tukey test. Statistical analysis revealed significant difference $(\mathrm{p} \leq 0.05)$ in interaction between treatment $\mathrm{x}$ cultivar. However, nonsignificant $(\mathrm{p} \leq 0.05)$ interaction in WUE between treatment $\mathrm{x}$ cultivar was observed.

Ionic parameters: Minimum leaf $\mathrm{Na}^{+}$contents were 
observed under non-saline conditions (control) while maximum was recorded at $12.5 \mathrm{dS} \mathrm{m}^{-1} \mathrm{NaCl}$, followed by $10.0,7.5,5.0$ and $2.5 \mathrm{dS} \mathrm{m}^{-1}$ (Fig. 1A). It was observed that minimum $\mathrm{Na}^{+}$contents were shown in N-Y LARA $(2.65 \mathrm{mg}$ $\left.\mathrm{g}^{-1} \mathrm{DW}\right)$ under non-saline environment followed by $720-110$ NARC (3.35 $\left.\mathrm{mg} \mathrm{g}^{-1} \mathrm{DW}\right)$ at same $\mathrm{NaCl}$ concentration. On the other hand, the maximum $\mathrm{Na}^{+}$contents were recorded in 720-110 NARC (28.8 $\left.\mathrm{mg} \mathrm{g}^{-1} \mathrm{DW}\right)$ at the highest salinity level $\left(12.5 \mathrm{dS} \mathrm{m}^{-1}\right)$ followed by N-Y LARA $\left(22.54 \mathrm{mg} \mathrm{g}^{-1}\right.$ $\mathrm{DW})$ at same saline treatment. On contrary, the highest $\mathrm{K}^{+}$ contents was recorded under non-saline environment as compared to those grown under various levels of salt stress $\left(2.5,5.0,7.5,10.0\right.$ and $\left.12.5 \mathrm{dS} \mathrm{m}^{-1}\right)$ in which $\mathrm{K}^{+}$contents continued to decrease with increasing salt stress (Fig. 1B). Moreover, cultivar's comparison revealed that N-Y LARA showed maximum $\mathrm{K}^{+}$contents $\left(62.1 \mathrm{mg} \mathrm{g}^{-1} \mathrm{DW}\right)$ under nonsaline environment while minimum $\mathrm{K}^{+}$contents $\left(10.3 \mathrm{mg} \mathrm{g}^{-1}\right.$ DW) were observed at salt stress level of $12.5 \mathrm{dS} \mathrm{m} \mathrm{m}^{-1}$ followed by $720-110$ NARC $\left(57.12 \mathrm{mg} \mathrm{g}^{-1} \mathrm{DW}\right.$ under control and $6.17 \mathrm{mg} \mathrm{g}^{-1} \mathrm{DW}$ under $12.5 \mathrm{dS} \mathrm{m} \mathrm{m}^{-1} \mathrm{NaCl}$ ) (Fig. 1B). The results concerning $\mathrm{Na}^{+}: \mathrm{K}^{+}$(Fig. 1C) revealed that maximum $\mathrm{Na}^{+}: \mathrm{K}^{+}$was observed in 720-110 NARC (4.67) followed by N-Y LARA (2.19) at $12.5 \mathrm{dS} \mathrm{m}^{-1} \mathrm{NaCl}$ level as compared to control.

Membrane stability index: Membrane stability index is estimated by measuring leaf electrolyte leakage (LEL). It continued to increase with increasing salinity levels (control, 2.5, 5.0, 7.5, 10.0 and $12.5 \mathrm{dS} \mathrm{m}^{-1}$ ). Results regarding LEL (Fig. 1D) elaborated that N-Y LARA exhibited less percentage increase in LEL i.e., $25.1 \%$ under 2.5 and $328.5 \%$ under $12.5 \mathrm{dS} \mathrm{m}^{-1} \mathrm{NaCl}$ levels relative to control, whereas 720-110 NARC showed higher percentage increase of $31.9 \%$ and $390.6 \%$ in LEL under 2.5 and $12.5 \mathrm{dS} \mathrm{m}^{-1}$ $\mathrm{NaCl}$ levels, respectively.

Water relation attributes: Application of various concentrations of salt $(\mathrm{NaCl})$ stress (control, 2.5, 5.0, 7.5, 10.0 and $12.5 \mathrm{dS} \mathrm{m}^{-1}$ ) resulted in reduced pre-dawn $\Psi_{\mathrm{w}}, \Psi \pi$, $\Psi \mathrm{p}$ and LRWC as presented in Figures 2A, 2B, 2C and 2D, respectively. N-Y LARA maintained the highest $\Psi_{W}(-0.23$ $\mathrm{MPa}), \Psi \pi(-0.89 \mathrm{MPA})$ and $\Psi \mathrm{p}(0.67 \mathrm{MPa})$ under non-saline treatment as compared to 720-110 NARC which maintained the lowest $\Psi_{\mathrm{w}}(-0.32 \mathrm{MPa}), \Psi \pi(-0.95 \mathrm{MPa})$ and $\Psi \mathrm{p}(0.63$ $\mathrm{MPa})$ under control. In parameters like $\Psi_{\mathrm{w}}, \Psi \pi, \Psi \mathrm{p}$ and
LRWC, N-Y LARA revealed $55.6 \%, 9.9 \%, 5.4 \%$ and $6.7 \%$ reduction, respectively, at $2.5 \mathrm{dS} \mathrm{m}^{-1} \mathrm{NaCl}$ relative to control whereas, $345.6 \%, 46.1 \%, 55.1 \%$ and $41.9 \%$ reduction was observed at $12.5 \mathrm{dS} \mathrm{m}^{-1} \mathrm{NaCl}$ level. However, 720-110 NARC exhibited $69.5 \%, 13.4 \%, 15.1 \%$ and $10.0 \%$ reduction in $\Psi \mathrm{w}, \Psi \pi, \Psi \mathrm{p}$ and LRWC at $2.5 \mathrm{dS} \mathrm{m}^{-1}$ while $374.1 \%$, $70.3 \%, 83.2 \%$ and $51.9 \%$ reduction in $\Psi \mathrm{w}, \Psi \pi, \Psi \mathrm{p}$ and LRWC, respectively, was expressed under $12.5 \mathrm{dS} \mathrm{m} \mathrm{m}^{-1}$ salinity levels relative to control. Likewise, the highest WUE was observed in N-Y LARA $(8.9 \%)$ at $2.5 \mathrm{dS} \mathrm{m}^{-1}$ salinity level followed by 720-110 NARC (7.8\%) relative to control (Table 1). However, under $12.5 \mathrm{dS} \mathrm{m} \mathrm{m}^{-1} \mathrm{NaCl}$, minimum percentage reduction in WUE was exhibited by N-Y LARA $(29.1 \%)$ followed by $720-110$ NARC $(35.35 \%)$ in comparison to control.

Gas exchange attributes: Potato cultivars exhibited a decreasing trend in $P n$ rate, $E$ rate and gs grown under 2.5, 5.0, 7.5, 10.0 and $12.5 \mathrm{dS} \mathrm{m}^{-1}$ salinity levels (Table 1). The highest $P n$ rate, $E$ rate and gs were noted in N-Y LARA i.e., $10.58\left(\mu \mathrm{mol} \mathrm{m} \mathrm{m}^{-2} \mathrm{~s}^{-1}\right), 4.96\left(\mathrm{mmol} \mathrm{m}^{-2} \mathrm{~s}^{-1}\right)$ and $0.43\left(\mathrm{mmol} \mathrm{m}^{-2}\right.$ $\left.\mathrm{s}^{-1}\right)$ respectively, followed by 720-110 NARC i.e., 8.71 $\left(\mu \mathrm{mol} \mathrm{m} \mathrm{m}^{-2} \mathrm{~s}^{-1}\right), 4.6\left(\mathrm{mmol} \mathrm{m} \mathrm{s}^{-2} \mathrm{~s}^{-1}\right)$ and $0.35\left(\mathrm{mmol} \mathrm{m} \mathrm{m}^{-2} \mathrm{~s}^{-1}\right)$, respectively, under control. Likewise, 720-110 NARC exhibited less percentage reduction in $P n$ rate $(22.93 \%), E$ rate $(28.5 \%)$ and $g s(24.8 \%)$ under $2.5 \mathrm{dS} \mathrm{m}^{-1} \mathrm{NaCl}$ concentrations compared to control while the highest percentage reduction was observed at $12.5 \mathrm{dS} \mathrm{m}^{-1} \mathrm{NaCl}$ in $P n$ rate $(89.12 \%), E$ rate $(83.1 \%)$ and $g s(82.7 \%)$ concentrations relative to control. However, N-Y LARA showed minimum percentage reduction at $2.5 \mathrm{dS} \mathrm{m}^{-1} \mathrm{NaCl}$ in $P n$ rate $(14.32 \%), E$ rate $(21.46 \%)$ and $g s(18.1 \%)$ relative to control whereas higher percentage reduction in $P n$ rate $(72.48 \%), E$ rate $(61.36 \%)$ and $g s(64.79 \%)$ was observed under $12.5 \mathrm{dS} \mathrm{m}^{-1}$ compared to control.

Antioxidant activities: Salt stress induced a marked acceleration in SOD, CAT and POD activities in both the tested potato cultivars (Tables 2). In N-Y LARA, minimum SOD, CAT and POD activities were noted under non-saline conditions i.e., $1.12,3.74$ and 2.16 Units $\mathrm{mg}^{-1}$ protein, respectively while maximum activities were observed at $12.5 \mathrm{dS} \mathrm{m}^{-1} \mathrm{NaCl}$ i.e., 2.66, 8.23, 4.39 Units $\mathrm{mg}^{-1}$ protein, respectively.

Table 1. Effect of salt stress on leaf photosynthetic activity $(P n)$, transpiration rate $(E)$, water use efficiency (WUE) and stomatal conductance ( $g s$ ) of potato cultivars.

\begin{tabular}{|c|c|c|c|c|c|c|c|c|}
\hline \multirow[t]{3}{*}{ Salt $\left(\mathrm{dS} \mathrm{m^{-1 } )}\right.$} & \multicolumn{2}{|c|}{$P n\left(\mu \mathrm{mol} \mathrm{m} \mathrm{m}^{-2} \mathrm{~s}^{-1}\right)$} & \multicolumn{2}{|c|}{ 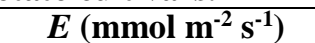 } & \multicolumn{2}{|c|}{ WUE (Pn/E) } & \multicolumn{2}{|c|}{$g s\left(\mathrm{mmol} \mathrm{m} \mathrm{m}^{-2} \mathrm{~s}^{-1}\right)$} \\
\hline & $\mathrm{N}-\mathrm{Y}$ & $720-110$ & $\mathrm{~N}-\mathrm{Y}$ & $720-110$ & $\mathrm{~N}-\mathrm{Y}$ & $720-110$ & $\mathrm{~N}-\mathrm{Y}$ & $720-110$ \\
\hline & LARA & NARC & LARA & NARC & LARA & NARC & LARA & NARC \\
\hline Control & $10.6 \mathrm{a}$ & $8.7 \mathrm{c}$ & $5.0 \mathrm{a}$ & $4.6 \mathrm{~b}$ & $2.1 \mathrm{~b}$ & $1.9 \mathrm{~cd}$ & $0.43 \mathrm{a}$ & $0.39 \mathrm{~b}$ \\
\hline 2.5 & $9.1 \mathrm{~b}$ & $6.7 \mathrm{~d}$ & $3.9 \mathrm{c}$ & $3.3 \mathrm{~d}$ & $2.3 \mathrm{a}$ & $2.0 \mathrm{bc}$ & $0.35 \mathrm{c}$ & $0.26 \mathrm{e}$ \\
\hline 5.0 & $6.0 \mathrm{e}$ & $3.3 \mathrm{~h}$ & $3.1 \mathrm{~d}$ & $2.1 \mathrm{~g}$ & $1.9 \mathrm{c}$ & $1.6 \mathrm{ef}$ & $0.27 \mathrm{~d}$ & $0.15 \mathrm{~g}$ \\
\hline 7.5 & $4.8 \mathrm{f}$ & $2.0 \mathrm{j}$ & $2.8 \mathrm{e}$ & $1.4 \mathrm{~g}$ & $1.7 \mathrm{de}$ & $1.5 \mathrm{fg}$ & $0.20 \mathrm{e}$ & $0.11 \mathrm{~h}$ \\
\hline 10.0 & $3.7 \mathrm{~g}$ & $1.4 \mathrm{k}$ & $2.4 \mathrm{f}$ & $1.0 \mathrm{i}$ & $1.6 \mathrm{ef}$ & $1.3 \mathrm{gh}$ & $0.18 \mathrm{f}$ & $0.08 \mathrm{i}$ \\
\hline 12.5 & $2.9 \mathrm{i}$ & 0.91 & $1.9 \mathrm{~g}$ & $0.8 \mathrm{i}$ & $1.5 \mathrm{f}$ & $1.2 \mathrm{~h}$ & $0.15 \mathrm{~g}$ & $0.06 \mathrm{j}$ \\
\hline
\end{tabular}

Every value in above figures is the mean of 4 replicates. Means followed by different letter(s) within a same column are significantly different according to HSD (Tuckey) test $(\mathrm{P} \leq 0.05)$. 
Table 2. Effect of salt stress on leaf total soluble protein contents, superoxide dismutase (SOD), catalase (CAT) and peroxidase (POD) activities of potato cultivars

\begin{tabular}{|c|c|c|c|c|c|c|c|c|}
\hline \multirow{3}{*}{$\begin{array}{c}\text { Salt } \\
\left(\mathrm{dSS} \mathrm{m}^{-}\right. \\
1)\end{array}$} & \multicolumn{2}{|c|}{ Protein $\left(\mathrm{mg} \mathrm{g}^{-1} \mathrm{FW}\right)$} & \multicolumn{2}{|c|}{ SOD $\left(\mathrm{U} \mathrm{mg}^{-1}\right.$ protein $)$} & \multicolumn{2}{|c|}{ CAT (U mg ${ }^{-1}$ protein) } & \multicolumn{2}{|c|}{ POD $\left(\mathrm{U} \mathrm{mg}^{-1}\right.$ protein $)$} \\
\hline & $\mathrm{N}-\mathrm{Y}$ & $720-110$ & $\mathrm{~N}-\mathrm{Y}$ & $720-110$ & $\mathrm{~N}-\mathrm{Y}$ & $720-110$ & $\mathrm{~N}-\mathrm{Y}$ & $720-110$ \\
\hline & LARA & NARC & LARA & NARC & LARA & NARC & LARA & NARC \\
\hline Control & $9.19 \mathrm{a}$ & $8.74 \mathrm{~b}$ & $1.1 \mathrm{fg}$ & $1.0 \mathrm{~g}$ & $3.7 \mathrm{fgh}$ & $2.8 \mathrm{~h}$ & $2.2 \mathrm{~h}$ & $1.7 \mathrm{i}$ \\
\hline 2.5 & $8.46 \mathrm{~b}$ & $7.49 \mathrm{c}$ & $1.4 \mathrm{ef}$ & $1.2 \mathrm{fg}$ & $4.5 \mathrm{ef}$ & $3.3 \mathrm{gh}$ & $2.7 \mathrm{f}$ & $2.0 \mathrm{~h}$ \\
\hline 5.0 & $7.58 \mathrm{c}$ & $5.41 \mathrm{f}$ & $1.8 \mathrm{~cd}$ & $1.4 \mathrm{ef}$ & $5.9 \mathrm{~cd}$ & $3.7 \mathrm{fgh}$ & $3.5 \mathrm{~d}$ & $2.4 \mathrm{~g}$ \\
\hline 7.5 & $6.61 \mathrm{~d}$ & $4.53 \mathrm{~g}$ & $2.1 \mathrm{bc}$ & $1.6 \mathrm{de}$ & $6.4 \mathrm{bc}$ & $4.3 \mathrm{efg}$ & $3.8 \mathrm{c}$ & $2.6 \mathrm{f}$ \\
\hline 10.0 & $5.83 \mathrm{e}$ & $3.92 \mathrm{~h}$ & $2.4 \mathrm{ab}$ & $1.8 \mathrm{~cd}$ & $7.2 \mathrm{ab}$ & $5.3 \mathrm{de}$ & $4.2 \mathrm{~b}$ & $2.8 \mathrm{ef}$ \\
\hline 12.5 & $5.14 \mathrm{f}$ & $3.29 \mathrm{i}$ & $2.7 \mathrm{a}$ & $1.9 \mathrm{~cd}$ & $8.2 \mathrm{a}$ & $6.5 \mathrm{bc}$ & $4.4 \mathrm{a}$ & $2.9 \mathrm{e}$ \\
\hline
\end{tabular}

Every value in above figures is the mean of 4 replicates. Means followed by different letter(s) within a same column are significantly different according to HSD (Tuckey) test $(\mathrm{P} \leq 0.05)$.

Table 3. Effect of salt stress on leaf proline contents, total phenolic contents and melondialdehyde (MDA) contents of potato cultivars

\begin{tabular}{|c|c|c|c|c|c|c|}
\hline \multirow[t]{2}{*}{ Salt $\left(\mathrm{dS} \mathrm{m}^{-1}\right)$} & \multicolumn{2}{|c|}{ Proline $\left(\mu\right.$ moles $\mathrm{g}^{-1}$ FW) } & \multicolumn{2}{|c|}{ Phenolic contents $\left(\mathrm{mg} \mathrm{g}^{-1} \mathrm{FW}\right)$} & \multicolumn{2}{|c|}{ MDA $\left(\mu\right.$ mole $\left.\mathrm{g}^{-1} \mathrm{FW}\right)$} \\
\hline & $\begin{array}{c}\mathrm{N}-\mathrm{Y} \\
\text { LARA }\end{array}$ & 720-110 NARC & N-Y LARA & 720-110 NARC & N-Y LARA & 720-110 NARC \\
\hline Control & $6.8 \mathrm{~g}$ & $6.1 \mathrm{~g}$ & $11.4 \mathrm{i}$ & $10.9 \mathrm{i}$ & $0.36 \mathrm{~h}$ & $0.49 \mathrm{gh}$ \\
\hline 2.5 & $9.3 \mathrm{ef}$ & $8.4 \mathrm{f}$ & $16.8 \mathrm{~g}$ & $13.5 \mathrm{~h}$ & $0.43 \mathrm{~h}$ & $0.75 \mathrm{ef}$ \\
\hline 5.0 & $11.1 \mathrm{~d}$ & $10.1 \mathrm{e}$ & $21.8 \mathrm{~d}$ & $15.9 \mathrm{~g}$ & $0.49 \mathrm{gh}$ & $0.98 \mathrm{~d}$ \\
\hline 7.5 & $13.2 \mathrm{c}$ & $11.8 \mathrm{~d}$ & $24.8 \mathrm{c}$ & $17.9 \mathrm{f}$ & $0.61 \mathrm{fg}$ & $1.34 \mathrm{c}$ \\
\hline 10.0 & $15.5 \mathrm{~b}$ & $13.2 \mathrm{c}$ & $26.9 \mathrm{~b}$ & $19.9 \mathrm{e}$ & $0.72 \mathrm{ef}$ & $1.51 \mathrm{~b}$ \\
\hline 12.5 & $19.2 \mathrm{a}$ & $15.2 \mathrm{~b}$ & $28.7 \mathrm{a}$ & $21.5 \mathrm{~d}$ & $0.87 \mathrm{de}$ & $1.77 \mathrm{a}$ \\
\hline
\end{tabular}

Every value in above figures is the mean of 4 replicates. Means followed by different letter(s) within a same column are significantly different according to HSD (Tuckey) test $(\mathrm{P} \leq 0.05)$

Table 4. Pearson Correlation Matrix of $\mathrm{Na}^{+}$with various ionic and physio-biochemical attributes.

\begin{tabular}{ccccccccc}
\hline & $\mathbf{K}^{+}$ & $\boldsymbol{P n}$ & WUE & LEL & SOD & CAT & Proline & MDA \\
\cline { 2 - 8 } $\mathrm{Na}^{+}$ & $-0.998^{*}$ & -0.976 & $-0.949^{*}$ & $0.991^{* *}$ & $0.999^{* *}$ & $0.982^{* *}$ & $0.986^{* *}$ & $0.991^{*}$ \\
\hline
\end{tabular}

Values indicate Pearson's correlation coefficient. *significant $(\mathrm{P}<0.05)$; **highly significant $(\mathrm{P}<0.01) . \mathrm{Na}^{+}$(sodium contents), $\mathrm{K}^{+}$(potassium contents), Pn (Photosynthetic activity), WUE (water use efficiency), LEL (leaf electrolyte leakage), SOD (superoxide dismutase), CAT (catalase) and MDA (Melondialdehyde)

On the other hand, 720-110 NARC exhibited the lowest values under control for SOD, CAT and POD activities (0.99, 2.8 and 1.74 Units $\mathrm{mg}^{-1}$ protein, respectively) while maximum activities (1.94, 6.5 and $2.94 \mathrm{Units}_{\mathrm{mg}^{-1}}$ protein, respectively) were observed at $12.5 \mathrm{dS} \mathrm{m}^{-1} \mathrm{NaCl}$.

Biochemical attributes: Data regarding total soluble proteins revealed that salt stress distinctly reduced total soluble proteins in both the investigated potato cultivars (Table 2). Nevertheless, maximum and minimum total soluble proteins were noticed under non-saline and $12.5 \mathrm{dS}$ $\mathrm{m}^{-1}$ salt stress level in N-Y LARA i.e. 9.1 and $5.1\left(\mathrm{mg} \mathrm{g}^{-1}\right.$ FW), respectively followed by 720-110 NARC (8.74 and 3.29 (mg g $\left.\mathrm{g}^{-1} \mathrm{FW}\right)$ under same salt stress treatments. Furthermore, salt stress induced a significant elevation in proline, total phenolic and MDA contents in both the tested potato cultivars (Table 3 ). Minimum and maximum proline, total phenolic and MDA contents were observed under nonsaline and $12.5 \mathrm{dS} \mathrm{m}^{-1} \mathrm{NaCl}$ treatment in $\mathrm{N}-\mathrm{Y}$ LARA i.e., 6.75 and 19.21 ( $\left.\mu \mathrm{mol} \mathrm{g}^{-1} \mathrm{FW}\right), 11.3$ and $28.68\left(\mathrm{mg} \mathrm{g}^{-1} \mathrm{FW}\right)$ and 0.35 and $0.87\left(\mu \mathrm{mol} \mathrm{g} \mathrm{g}^{-1} \mathrm{FW}\right)$, respectively, followed by 720-110 NARC i.e. 6.11 and $15.24\left(\mu \mathrm{mol} \mathrm{g} \mathrm{g}^{-1} \mathrm{FW}\right), 10.9$ and $21.55\left(\mathrm{mg} \mathrm{g}^{-1} \mathrm{FW}\right)$ and 0.49 and 1.77 ( $\left.\mu \mathrm{mol} \mathrm{g}^{-1} \mathrm{FW}\right)$, respectively, compared to control (Table 3 ).

\section{DISCUSSION}

Salt stress in plants negatively influences morphological, physiological and biochemical attributes. Plants have acquired different levels of tolerance and sensitivity based upon their types and adaptation (Abbas et al., 2015). Some 


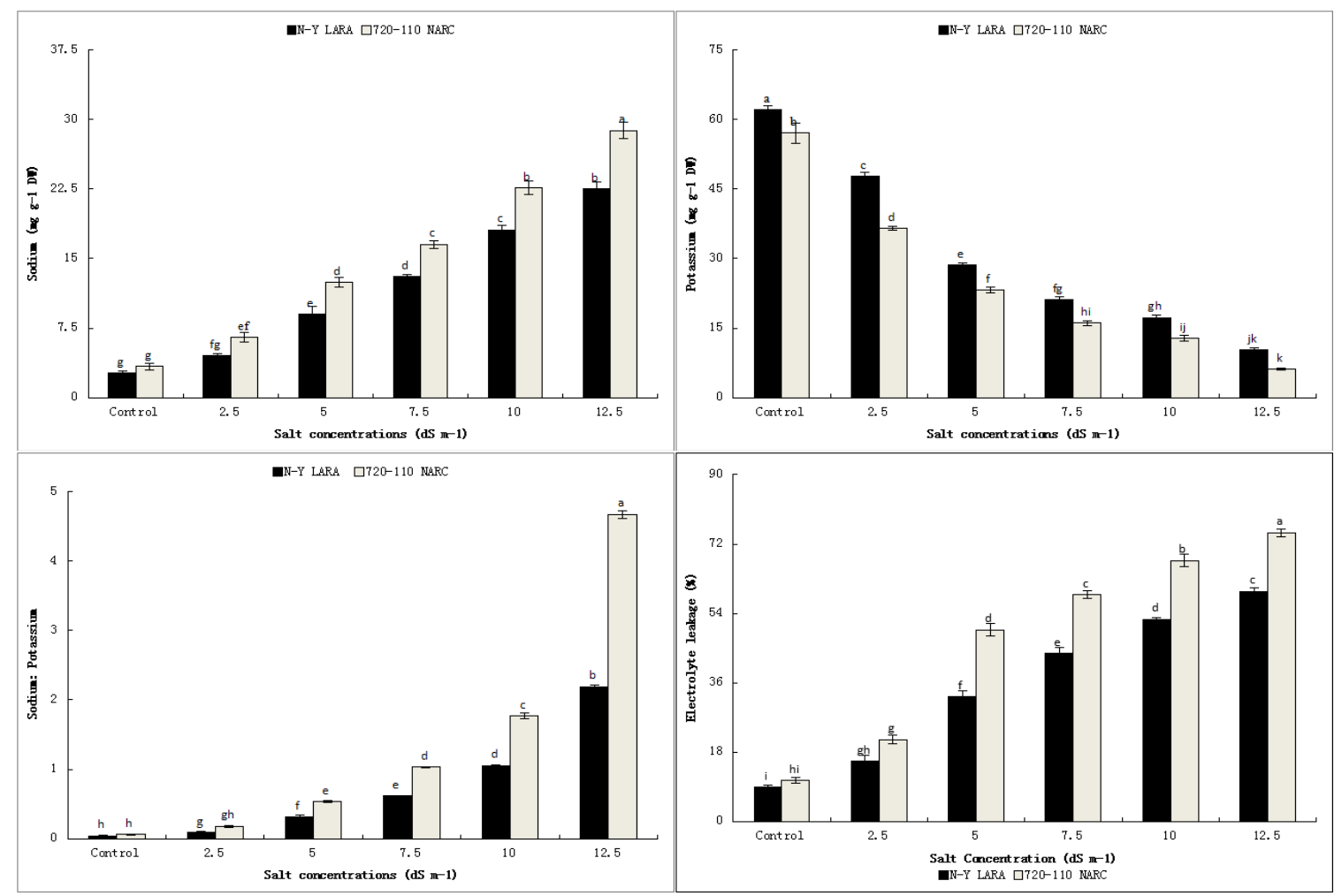

Every value in above figures is the mean of 4 replicates and vertical bars give standard error (SE) of the means. HSD (Tuckey Test) for cultivar and treatments were significant at $\mathrm{p} \leq 0.05$.

Figure 1. Effect of salt stress on leaf (A) Sodium $\left(\mathrm{Na}^{+}\right)$concentration $\left(\mathrm{mg} \mathrm{g}^{-1} \mathrm{DW}\right)$, (B) Potassium (K+) concentration, (C) $\mathrm{Na}^{+}$: $\mathrm{K}^{+}$and electrolyte leakage (LEL) (\%) of potato cultivars.

plant species have developed modifications at cellular and sub-cellular levels by accumulating salts in their vacuoles more effectively in contrast to salt sensitive ones (Fidalgo et al., 2004; Aghaei et al., 2008; Maksimovic and Ilin, 2012). In present study, potato cultivar N-Y LARA proved to be tolerant as compared to $720-110$ NARC based upon its physiology and biochemical attributes.

Salt stress reduces rhizosphere osmotic potential which becomes more negative with increasing salt levels leading to cell dehydration due to water efflux from cell (Rahnama et al., 2010; Amjad et al., 2014). In present study, higher $\mathrm{Na}^{+}$ contents (Fig. 1A) and lowers $\mathrm{K}^{+}$contents (Fig 1B) were found in potato leaves under salinity stress. However, N-Y LARA revealed comparatively low concentration of $\mathrm{Na}^{+}$and greater $\mathrm{K}^{+}$contents as compared to 720-110 NARC. This trend might be due to genetic variability, root permeability to these ions (Akram et al., 2010; Mishra et al., 2013) and $\mathrm{Na}^{+}$distribution from roots to leave tissues in studied cultivars (Jaarsma et al., 2013). Moreover, Sodium ions $\left(\mathrm{Na}^{+}\right)$on their way from roots to shoot via transpiration stream progressively buildup in vacuoles and later on shifts to cytoplasm of older leaves causing ionic toxicity and injury in cells with increased salt stress severity. Hence, elevated $\mathrm{Na}^{+}$level reduces $\mathrm{K}^{+}$uptake and depletes its contents in guard cells hindering stomatal regulation (Parvaiz and
Satyawati, 2008). $\mathrm{Na}^{+}$accumulation enhanced $\mathrm{Na}^{+}: \mathrm{K}^{+}$ratio which continues to increase with increasing salt stress (Aghaei et al., 2008; Maathuis, 2014; Zhang and Shi, 2013) as observed in present study (Fig. 1C). Besides, the correlation matrix table (Table 4) is elaborating that various variables are interlinked with each other. $\mathrm{Na}^{+}$had significant and highly negative correlation with $\mathrm{K}^{+}, P n$ and WUE. Whereas, highly positive and significant correlation of $\mathrm{Na}^{+}$ was noted with LEL, SOD, CAT, proline and MDA.

Likewise, during present study increasing salt stress resulted in reduced $\Psi_{\mathrm{w}}$ (Fig. 2A), $\Psi \pi$ (Fig. 2B), $\Psi$ p (Fig. 2C) and LRWC (Fig. 2D). Accumulation of soluble salts in rhizosphere decrease soil $\Psi \mathrm{w}$ compared to root cells (Tuteja, 2007). This reduces water influx to plant roots leading to physiological drought and buildup of solutes in roots and later on, in leaf cells which drops leaf cell's $\Psi_{\mathrm{w}}$ and $\Psi \pi$. This condition leads to hyperosmotic stress as leaves continue to transpire while water uptake from soil is reduced drastically. Hence, reduced water uptake and turgor maintenance result in osmotic stress, ionic imbalance and toxicity due to salt stress which in turn reduces cellular $\Psi \mathrm{p}$, LRWC, stomatal area and closure of stomata (Mishra, 2013; Gao et al., 2015; Farooq et al., 2015). Similarly, WUE, decreased under salt stress as 


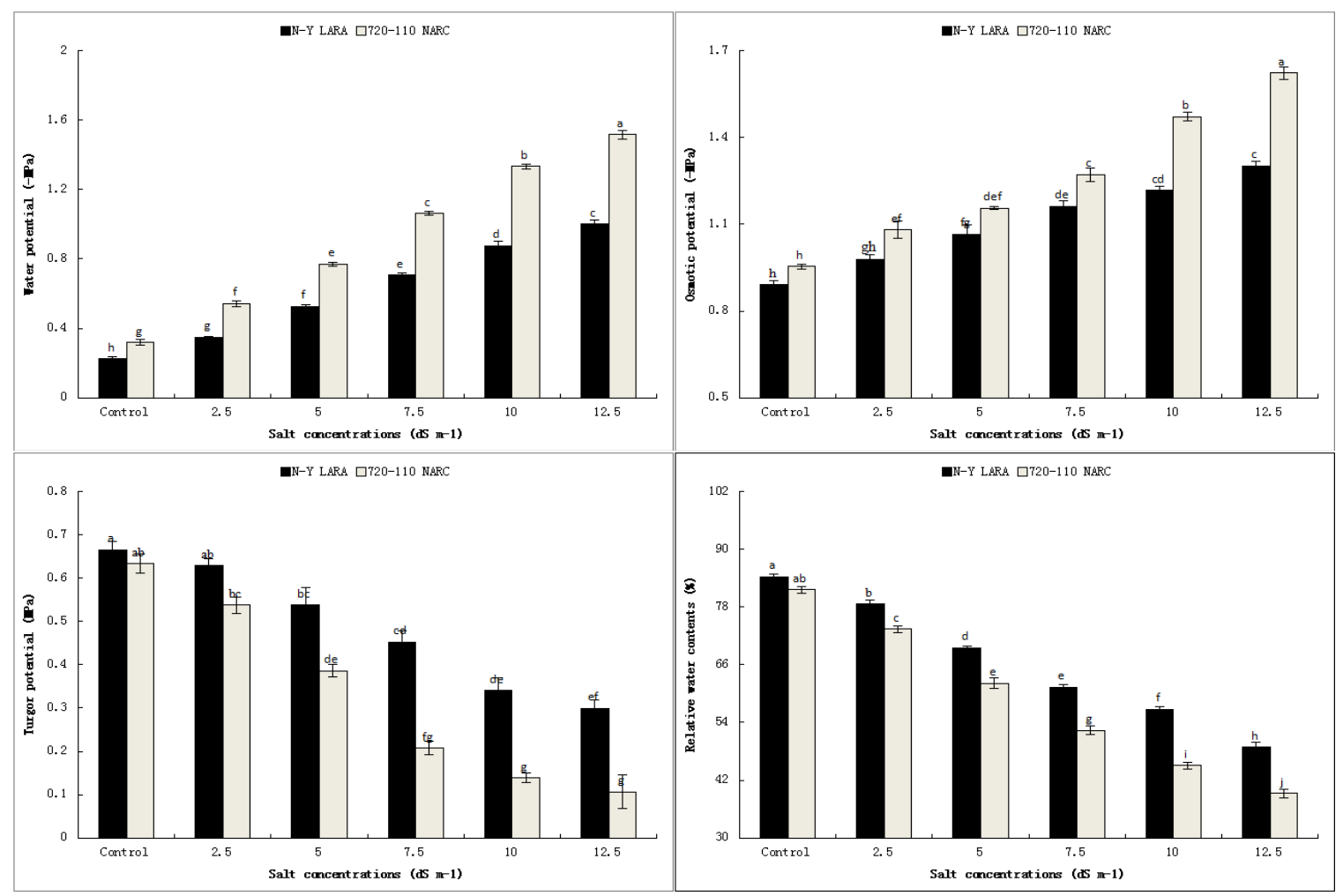

Every value in above figures is the mean of 4 replicates and vertical bars give standard error (SE) of the means. HSD (Tuckey Test) for cultivar and treatments were significant at $\mathrm{p} \leq 0.05$.

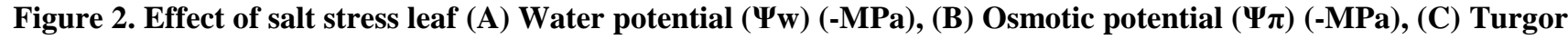
potential ( $\Psi$ p) (MPa) and (D) Relative water contents (LRWC) (\%) of potato cultivars.

reported in present study (Table 1). Salinity stress results in reduced leaf area, osmotic stress, ionic toxicity, $g s, P n$ and $E$ which in turn reduces WUE in plant species (Grewal, 2010; Odemiş and CaliSkan 2014). However, increased WUE at low salinity level as in present study at $2.5 \mathrm{dS} \mathrm{m} \mathrm{m}^{-1} \mathrm{NaCl}$ (Table 1) may be attributed to increased functioning of aquaporin that enhanced membrane permeability to water and $\mathrm{CO}_{2}$ in order to maintain plant cell water balance (Kaldenhoff and Fischer, 2003).

It is evident from the results that salt stress significantly inhibited Pn (Table 1), E (Table 1) and $g s$ (Table 1) in the tested potato cultivars which is in accordance with the findings of Fidalgo et al. (2004) and Odemiş and Calişkan (2014). Salt stress influences gas exchange parameters through impaired intercellular $\mathrm{CO}_{2}$ concentration (RomeroAranda et al., 2001; Navarro et al., 2007), toxic ion's buildup in leaf cells, reduced canopy size, condensed $P n$ pigments, and altered activities of photosynthetic enzymes (Rahnama et al., 2010; Ashraf and Harris, 2013). Besides, salinity stress enhances ABA accumulation in stomatal guard cells due to salt initiated osmotic stress. Osmotic stress in turn reduces guard cell turgidity, narrows the orifice of stomata and leads to stomatal closure under severe salt stress (Wilkinson and Davies, 2002; Ashraf and Harris, 2013). Hence, salt induced physiological drought (Aghaei et al., 2008; Farooq et al., 2015) and closure of stomata reduces $g s$ as observed in present study (Table 1). Additionally, $g s$ is presumed to be the most affected attribute by salinity compared to other gas exchange parameters as $g s$ is directly controlled by $\Psi_{\mathrm{w}}$ in roots and concentration of ABA in xylem sap (Tardieu et al., 1991; Akram and Ashraf, 2013; Odemiş and Caliskan, 2014).

Excessive accumulation of $\mathrm{Na}^{+}$in cytosol directly affects membrane stability through enhanced generation of MDA contents and leakage of electrolytes, which further aggravated with increasing salinity stress (Gao et al., 2015). Similarly, in present study, salt stress enhanced MDA contents (Table 3) and leaf electrolyte leakage (Fig. 1D). Maximum MDA contents and electrolyte leakage percentage were observed in 720-110 NARC relative to N-Y LARA cultivar. Salt stress intensifies ROS and inflicts oxidative stress that disturbs cytosolic metabolic activities (Zhu, 2001) 
and increased leaf MDA contents (Gao et al., 2015). Thereby, enhances cellular damages like disintegration of membrane constituents and enhanced electrolyte leakage (Ismail et al., 2014). Although significant antioxidant enzymes like SOD, CAT and POD, production was observed under salt stress but their induction was not enough to eliminate ROS. It results into higher accumulation of MDA contents (Table 3) and cellular membrane damage (Fig. 1D) which further enhanced with increasing salt stress (Gao et $a l ., 2015)$. Reduction in total soluble proteins were found in present study (Table 2) as reported by Aghaei et al., (2008) who identified reduction in total chlorophyll and protein contents.

Plant's cellular adaptive responses for salt tolerance involve acceleration of ROS scavenging antioxidant system such as SOD, CAT, POD (Mishra et al., 2013) and osmotic adjustment (e.g., proline, total phenolic contents) (Huang et al., 2013; Miljus-Djukic et al., 2013. In current study, enhanced production of antioxidant enzymes (SOD, CAT, POD) (Table 2) and osmolytes (Proline, total phenolic contents) (Table 3) were observed which continued to increase with increasing salt stress. ROS scavenging enzymes produce more during abiotic stresses. Antioxidant system (e.g., SOD, CAT, POD) maintains ROS to a less toxic level naturally within cell by converting ROS into water and oxygen. Superoxide dismutase (SOD) enzyme converts superoxide into $\mathrm{H}_{2} \mathrm{O}_{2}$ that is scavenged by CAT and peroxidases (POD) by converting it into water through Halliwell-Asada pathway (Asada and Takahashi, 1987; Chen et al., 2011; Bhattacharjee, 2012). Moreover, plants offset salinity stress by an accumulation of osmo-protectants like proline, that increases with increase in salinity and help to maintain water uptake, cell turgor, osmo-regulation and thereby normal physiological metabolism (Huang et al., 2013; Gao et al., 2015). Proline accumulated more in tolerant cultivar compared to sensitive one (Bojorquezquintal et al., 2014) as observed in present study (Table 3). Total phenolic contents increased with increase in salinity (Table 3). Furthermore, there is a strong correlation between high concentration of total phenolic, antioxidants and abiotic stresses like salinity (Wahid and Ghazanfar, 2006; Noreen and Ashraf, 2009; Miljus-Djukic et al., 2013).

Conclusions: Salt stress significantly affected ionic, water relation, gas exchange, antioxidant and biochemical attributes of potato. Moreover, genetic variations are found in potato cultivars as both the studied cultivars respond variably under salt stress. N-Y LARA proved tolerant cultivar than 720-110 NARC which testified as a salt sensitive cultivar due to its less tolerance mechanisms against salinity. Thus, N-Y LARA can successfully be grown in saline zones as it generated higher antioxidants, proline and total phenolic contents which continued to increase with increasing oxidative stress.
Acknowledgement: The authors are grateful to the Vegetable Section, Institute of Horticultural Sciences, University of Agriculture, Faisalabad and Higher Education Commission of Pakistan for their every type of support.

\section{REFERENCES}

Abbas, G., M. Saqib, J. Akhtar, G. Murtaza and M. Shahid. 2015. Effect of salinity on rhizosphere acidification and antioxidant activity of two Acacia species. Can. J. Forest Res. 45:124-129.

Abhayapala, K., W.D. Costa, R. Fonseka, K. Prasannath, D.D. Costa, L. Suriyagoda, P. Abeythilakeratne and M. Nugaliyadde. 2014. Response of potato (Solanum tuberosum L.) to increasing growing season temperature under different soil management and crop protection regimes in the upcountry of Sri Lanka. Trop. Agric. Res. 25:455-469.

Aghaei, K., A.A. Ehsanpour and S. Komatsu. 2008. Potato responds to salt stress by increased activity of antioxidant enzymes. J. Integ. Plant Biol. 51:1095-1103.

Akram, M., M.Y. Ashraf, R. Ahmad, E.A. Waraich, J. Iqbal and M. Mohsan. 2010. Screening for salt tolerance in maize (Zea mays) hybrids at an early seedling stage. Pak. J. Bot. 42:141-154.

Akram, N.A. and M. Ashraf. 2013. Improvement in growth, chlorophyll pigments and photosynthetic performance in salt-stressed plants of sunflower (Helianthus annuus L.) by foliar application of 5-aminolevulinic acid. Agrochimica 55:94-104.

Amjad, M., J. Akhtar, M. Anwar-ul-Haq, A. Yang, S.C. Akhtar and E. Jacobsen. 2014. Integrating role of ethylene and ABA in tomato plants adaptation to salt stress. Sci. Hortic. 172:109-116.

Anonymous. 2010. Pakistan Statistics Year Book. Federal Bureau of Statistics, Statistics Division, Government of Pakistan, Islamabad, Pakistan.

Asada, K. and M. Takahashi. 1987. Production and scavenging of active oxygen in chloroplasts. p. 227-287. In: D.J. Kyle, C.B. Osmond and C.J. Arntzen (eds.), Photoinhibition. Elsevier, Amsterdam.

Ashraf, M. and P.J.C. Harris. 2013. Photosynthesis under stressful environments: An overview. Photosynthetica 51:163-190.

Bates, L., R. Waldren and I. Teare. 1973. Rapid determination of free proline for water-stress studies. Plant Soil 39:205-207.

Bhattacharjee, S. 2012. The language of reactive oxygen species signaling in plants. J. Bot. doi:10.1155/2012/985298.

Bojorquez-quintal, J., A. Velarde, A. Ku, M. Carrillo, D. Ortega and I. Echevarria. 2014. Mechanisms of salt tolerance in habanero pepper plants (Capsicum chinense Jacq.): proline accumulation, ions dynamics, root-shoot 
partition and compartmentation. Front. Plant Sci. 5:605611.

Bruns, S. and C. Hecht-Buchholz. 1990. Light and electron microscope studies on the leaves of several potato cultivars after application of salt at various development stages. Potato Res. 33:33-41.

Chance, B. and C. Maehly. 1955. Assay of catalase and peroxidases. Methods Enzymol. 2:764-775.

Chen, Q., M. Zhang and S. Shen. 2011. Effect of salt on malondialdehyde and antioxidant enzymes in seedling roots of Jerusalem artichoke (Helianthus tuberosus L.). Acta Physiol. Plant. 33:273-278.

Choudhury, S., P. Panda, L. Sahoo and S.K. Panda. 2013. Reactive oxygen species signaling in plants under abiotic stress. Plant Signal. Behav. 8:1-6.

Farkhondeh, R., E. Nabizadeh and N. Jalilnezhad. 2012. Effect of salinity stress on proline content, membrane stability and water relations in two sugar beet cultivars. Int. J. Agric. Sci. 2:385-392.

Farooq, M., M. Hussain, A. Wakeel, H. Kadambot and M. Siddique. 2015. Salt stress in maize: effects, resistance mechanisms, and management: A review. Agron. Sustain. Dev. 35:461-481.

Fidalgo, F., A. Santos, I. Santos and R. Salema. 2004. Effects of long-term salt stress on antioxidant defense systems, leaf water relations and chloroplast ultrastructure of potato plants. Ann. appl. Biol. 145:185-192.

Gao, H.J., H.Y. Yang, J.P. Bai, X.Y. Liang, Y. Lou, J.L. Zhang, D. Wang, J.L. Zhang, S.Q. Niu and Y. Chen. 2015. Ultrastructural and physiological responses of potato (Solanum tuberosum) plantlets to gradient saline stress. Front. Plant Sci. 5:1-14.

Giannopolitis, C.N. and S.K. Ries. 1977. Superoxide dismutase. I. Occurrence in higher plants. Plant Physiol. 59:309-314.

Gill, S.S. and N. Tuteja. 2010. Reactive oxygen species and antioxidant machinery in abiotic stress tolerance in crop plants. Plant Physiol. Biochem. 48:909-930.

Grewal, H.S. 2010. Water uptake, water use efficiency, plant growth and ionic balance of wheat, barley, canola and chickpea plants on a sodic vertosol with variable subsoil $\mathrm{NaCl}$ salinity. Agric. Water Manag. 97:148-156.

Gupta, B. and B. Huang. 2014. Mechanism of salinity tolerance in plants: physiological, biochemical, and molecular characterization. Int. J. Genomics 214: 1-18.

Gururani, M.A., C.P. Upadhyaya, R.J. Strasser, J.W. Yu and S.W. Park. 2013. Evaluation of abiotic stress tolerance in transgenic potato plants with reduced expression of PSII manganese stabilizing protein. Plant Sci. 198:7-16.

Hasanuzzaman, M., K. Nahar and M. Fujita. 2013. Plant response to salt stress and role of exogenous protectants to mitigate salt-induced damages, p.25-87. In: P. Ahmad, M.M. Azooz and M.N.V. Parasad (eds.), Ecophysiology and responses of plants under salt stress. Springer Science + Business Media, LLC.

Heath, R.L. and L. Packer. 1968. Photoperoxidation in isolated chloroplasts: I. Kinetics and stoichiometry of fatty acid peroxidation. Arch. Biochem. Biophys. 125:189-198.

Hmida-Sayari, A., R. Gargouri-Bouzid, A. Bidani, L. Jaoua, A. Savoure and S. Jaoua. 2005. Overexpression of $\Delta 1$ pyrroline-5-carboxylate synthetase increases proline production and confers salt tolerance in transgenic potato plants. Plant Sci. 169:746-752.

Horie, T., I. Karahara and M. Katsuhara. 2012. Salinity tolerance mechanisms in glycophytes: An overview with the central focus on rice plants. Rice 5:1-18.

Huang, Z., L. Zhao, D. Chen, M. Liang, Z. Liu and H. Shao. 2013. Salt stress encourages proline accumulation by regulating proline biosynthesis and degradation in Jerusalem artichoke plantlets. PloS One 8:1-11.

Iqbal, M.M., M.A. Goheer and A.M. Khan. 2009. Climate change aspersion on food security of Pakistan. Sci. Vision 15:15-23.

Ismail, A., S. Takeda and P. Nick. 2014. Life and death under salt stress: same players, different timing? J. Exp. Bot. 65:2963-2979.

Jaarsma, R., S. Rozemarijin, M. de Vries, H. Albertus and H. De-Boer. 2013. Effect of salt stress on growth, $\mathrm{Na}^{+}$ accumulation and proline metabolism in potato (Solanum tuberosum L.) cultivars. PLoS One 8:1-10.

Jbir-Koubaa, R., S. Charfeddine, W. Ellouz, M.N. Saidi, N. Drira, R. Gargouri-Bouzid and O. Nouri-Ellouz. 2014. Investigation of the response to salinity and to oxidative stress of interspecific potato somatic hybrids grown in a greenhouse. Pl. Cell Tiss. Org. Cult. 120:933-947.

Julkunen-Tiitto, R. 1985. Phenolic constituents in the leaves of northern willows: methods for the analysis of certain phenolics. J. Agric. Food Chem. 33:213-217.

Kaldenhoff, R. and M. Fischer. 2006. Aquaporins in plants. Acta Physiol. 187:169-176.

Kaouther, Z., B.F. Mariem, M. Fardaous and H. Cherif. 2012. Impact of salt stress $(\mathrm{NaCl})$ on growth, chlorophyll content and fluorescence of Tunisian cultivars of chili pepper (Capsicum frutescens L.). J. Stress Physiol. Biochem. 8:236-252.

Li, T., Y. Hu, X. Du, H. Tang, C. Shen and J. Wu. 2014. Salicylic acid alleviates the adverse effects of salt stress in Torreya grandis cv. Merrillii seedlings by activating photosynthesis and enhancing antioxidant systems. PLoS One 9:1-9. 
Lowry, O.H., R.N.J. Usenbrough, A.L. Far and R.J. Randall. 1951. Protein measurement with the folin's reagent. J. Biol. Chem. 193:265-266.

Maathuis, F.J. 2014. Sodium in plants: perception, signaling, and regulation of sodium fluxes. J. Exp. Bot. 65:849858.

Maksimovic, I. and Z. Ilin. 2012. Effects of salinity on vegetable growth and nutrients uptake, p.169-190. In: T.S. Lee (ed.), Irrigation Systems and Practices in Challenging Environments. Shanghai, 200040, China.

Malik, K.M., A. Mahmood, D.H. Kazmi and J.M. Khan. 2012. Impact of climate change on agriculture during winter season over Pakistan. Agric. Sci. 3:1007-1018.

Miljus-Djukic, J., N. Stanisavljevic, S. Radovic, Z. Jovanovic, A. Mikic and V. Maksimovic. 2013. Differential response of three contrasting pea (Pisum arvense, $P$. sativum and $P$. fulvum) species to salt stress: assessment of variation in antioxidative defense and miRNA expression. Aust. J. Crop Sci. 7:2145-2153.

Mishra, P., K. Bhoomika and R. Dubey. 2013. Differential responses of antioxidative defense system to prolonged salinity stress in salt-tolerant and salt sensitive Indica rice (Oryza sativa L.) seedlings. Protoplasma 250:3-19.

Mitsuya, S., Y. Takeoka and H. Miyake. 2000. Effects of Sodium Chloride on foliar ultrastructure of sweet potato (Ipomoea batatas Lam) plantlets grown under light and dark conditions in vitro. J. Plant Physiol. 157:661-667.

Mou, B. 2011. Improvement of horticultural crops for abiotic stress tolerance: An introduction. Hort. Sci. 46:1068-1069.

Munns, R. and M. Tester. 2008. Mechanisms of salinity tolerance. Annu. Rev. Plant Biol. 59:651-681.

Navarro, A., S. Banon, E. Olmos and M.D.J. SanchezBlanco. 2007. Effects of sodium chloride on water potential components, hydraulic conductivity, gas exchange and leaf ultrastructure of Arbutus unedo plants. Plant Sci. 172:473-480.

Noreen, S., M. Ashraf, M. Hussain and A. Jamil. 2009. Exogenous application of salicylic acid enhances antioxidative capacity in salt stressed sunflower (Helianthus annuus L.) plants. Pak. J. Bot. 41:473-479.

Odemis, B. and M.E. Çaliskan. 2014. Photosynthetic response of potato plants to soil salinity. Turk. J. Agric. Nat. Sci. 2:1429-1439.

Parvaiz, A. and S. Satyawati. 2008. Salt stress and phytobiochemical responses of plants. A review. Plant Soil Environ. 54:89-99.

Rahnama, H. and H. Ebrahimzadeh. 2004. The effect of $\mathrm{NaCl}$ on proline accumulation in potato seedlings and calli. Acta Physiol. Plant. 26:263-270.

Romero-Aranda, R., T. Soria and J. Cuartero. 2001. Tomato plant-water uptake and plant-water relationships under saline growth conditions. Plant Sci. 160:265-272.

Tardieu, F., N. Katerji, O. Bethenod, J. Zhang and W. Davies. 1991. Maize stomatal conductance in the field: Its relationship with soil and plant water potentials, mechanical constraints and ABA concentration in the xylem sap. Plant Cell Environ. 14:121-126.

Tuteja, N. 2007. Chapter twenty-four-mechanisms of high salinity tolerance in plants. Methods Enzym. 428:419438.

Wahid, A. and A. Ghazanfar. 2006. Possible involvement of some secondary metabolites in salt tolerance of sugarcane. J. Plant Physiol. 163:723-730.

Wilkinson, S. and W.J. Davies. 2002. ABA-based chemical signaling: the co-ordination of responses to stress in plants. Plant Cell Environ. 25:195-210.

Yamasaki, S. and L.R. Dillenburg. 1999. Measurements of leaf relative water content in Araucaria angustifolia. Revista. Brasilleira de Fisiologia Vegetal. 11:69-75.

Yoshida, S., D.A. Forno, J.L., Cock and K.A. Gomez. 1976. Laboratory manual for physiological studies of rice. IRRI, Los Banos, Philippines. pp. 27-34.

Zhang, J.L. and H. Shi. 2013. Physiological and molecular mechanisms of plant salt tolerance. Photosynth. Res. 115:1-22.

Zhu, J.K. 2001. Cell signaling under salt, water and cold stresses. Curr. Opin. Plant Biol. 4:401-406. 